\title{
HUBUNGAN KELINCAHAN DAN DAYA LEDAK OTOT TUNGKAI TERHADAP KECEPATAN TENDANGAN SABIT ATLET PENCAK SILAT SILATURAHMI KALUMBUK KECAMATAN KURANJI KOTA PADANG
}

\author{
Rosmawati $^{1}$, Darni ${ }^{2}$, Hilmainur Syampurma ${ }^{3}$ \\ Jurusan Pendidikan Olahraga Prodi. Pendidikan Jasmani Kesehatan dan Rekreasi Fakultas Ilmu \\ Keolahragaan. Jalan Prof. Dr. Hamka Air Tawar Barat, Padang 25132, Indonesia Universitas Negeri \\ Padang
}

\begin{abstract}
Abstrak
Masalah penelitian ini adalah lemahnya tendangan sabit atlit silat Silahturahmi Kalumbuk Kec.Kuranji Padang disebabkan karena banyak faktor.Penelitian ini bertujuan untuk mengungkapkan bagaimana hubungan kelincahan dan daya ledak otot tungkai secara bersama-sama terhadap kecepatan tendangan sabit Atlet Pencak Silat Silahturahmi Kalumbuk Kec.Kuranji Padang. Populasi penelitian atlit Atlet Pencak Silat Silahturahmi Kalumbuk Kec.Kuranji Padang. Teknik penarikan sampel dengan total sampling, maka sampel pada penelitian ini ditetapkan sebanyak 30 orang. Hasil analisis data menunjukan bahwa: Terdapat hubungan secara bersama-sama antara kelincahan dan daya ledak otot tungkai terhadap kecepatan tendangan sabit atlet pencak silat Silaturahmi Kalumbuk Kecamatan Kuranji Kota Padang. Dimana diperoleh $\mathrm{r}_{\mathrm{o}}=0,98>\mathrm{L}_{\mathrm{tab}}=0,361$ pada taraf pengujian signifikan $\alpha=0,05$ kontribusi sebesar $=46,4 \%$
\end{abstract}

Kata Kunci: Kelincahan, Daya Ledak Otot Tungkai dan kecepatan tendangan sabit.

\section{RELATIONSHIP OF RELATIONSHIP AND POWER IN THE MUSCLE OF THE BREAK AGAINST SPEED TICKET ATCLET ATTACK SILAT SILATAHMI KALUMBUK KECAMATAN KURANJI KOTA PADANG}

\begin{abstract}
The Problems this research were the weakened a scythe athletes Silahturahmi Kalumbuk Kec.Kuranji Padang.This research aims to to express what is the relationship agility and explosive power limb muscles together to a scythe athletes Silahturahmi Kalumbuk Kec.Kuranji Padang. Population research is athletes Silahturahmi Kalumbuk Kec.Kuranji Padang. Technique withdrawal sample with a total of sampling, so samples to research is established as many as 30 people. The result of the analysis data showed that there are relations together between agility and explosive power limb muscles together to a scythe athletes Silahturahmi Kalumbuk Kec.Kuranji Padang where obtained the first significant $\alpha=0,05$ and contributing of $46,4 \%$.
\end{abstract}

Keywords : agility, explosive power limb muscles, a scythe athletes

\section{Pendahuluan}

Pencak silat merupakan salah satu cabang olahraga yang dipertandingkan baik ditingkat daerah, nasional, regional, dan bahkan ditingat Internasional, mulai usia dini, remaja dan sampai usia dewasa. Perkembangan olahraga pencak silat sekarang ini cukup membanggakan dengan semakin tersebarnya perguruan pencak silat di nusantara dan bahkan diluar Negara Indonesia. Dalam UU RI No. 3 Tahun 2005 pasal 4 tentang Sistem Keolahragaan Nasional bahwa :

"Keolahragaan nasional bertujuan memelihara dan meningkatkan kesehatan dan kebugaran, prestasi, kualitas manusia, menanamkan nilai moral dan akhlak mulia, sportivitas, disiplin, mempererat dan membina persatuan bangsa, memperkukuh pertahanan nasional, serta mengangkat harkat, martabat, dan kehormatan bangsa."

Dari kutipan di atas dapat diambil kesimpulan bahwa pembangunan olahraga sangatlah penting dikembangan sehingga terbentuk manusia yang sehat secara jasmani dan rohani serta meliliki Akhlak mulia dan untuk meningkatkan persatuan dan kesatuan bangsa. 
Keberhasilan seorang pesilat dalam pertandingan dapat dipengaruhi oleh kualitas kondisi fisik, keterampilan teknik yang dimiliki, penggunaan teknik dalam bertanding, dan kematangan dalam melakukan teknik tersebut. Teknik dasar yang perlu dikuasai dan sering digunakan oleh seorang pesilat dalam bertanding antara lain adalah: kuda-kuda, sikap pasang, langkah, teknik belaan, teknik serangan, teknik jatuhan, teknik tangkapan. Dimana dalam teknik serangan terdapat suatu teknik tendangan yang salah satunya teknik tendangan sabit. Tendangan sabit adalah salah satu teknik yang dilakukan dengan mengayunkan kaki dari samping luar menuju samping dalam.

Tendangan sabit sangat diperlukan sekali dengan olahraga pencak silat, karena tendangan sabit merupakan salah satu teknik dasar dalam olahraga pencak silat khususnya dalam kategori laga atau tanding. Begitu pentingnya penguasaan teknik dasar, khususnya tektik tendangan sabit bagi pencapaian prestasi maksimal seorang pesilat, maka sewajarnyalah bila hal ini mendapat perhatian serius bagi pelatih ataupun atlet itu sendiri. Untuk mencapai prestasi maksimal dalam olahraga pencak silat, dibutuhkan beberapa aspek seperti: kondisi fisik, teknik, taktik dan mental pesilat. Hal ini perlu diperhatikan oleh seorang pesilat dengan bantuan dan arahan pelatih.

Berdasarkan pengamatan yang dilihat pada perguruan silat Silahturahmi Kalumbuk Kec.Kuranji Padang saat sparing para pesilat kurang dapat melakukan tendangan sabit secara efektif, serangan ini akan mudah di antisipasi oleh lawannya dan mudah di tangkap. Akhirnya para pesilat ini akan sering mudah kalah dalam mendapatkan point. Pada saat latihan dan uji coba banyak tendangan sabitnya yang tidak tepat pada sasaran dan mudah ditangkap oleh lawan. Maka diduga masih lemahnya tendangan sabit atlit silat Silahturahmi Kalumbuk Kec.Kuranji Padang disebabkan karena banyak faktor.

Pencak silat itu pada dasarnya adalah pembelaan diri dari insan Indonesia untuk menghindarkan diri dari segala malapetaka. Istilah bagi seni pembelaan diri bangsa Indonesia dengan nama PENCAK SILAT, dikukuhkan pada Seminar Pencak Silat tahun 1973 di Tutu Bogor.Dimasa lalu tidak semua daerah di Indonesia menggunakan istilah pencak silat. Di beberapa daerah jawa lazimnya digunakan nama Pencak, di sumatera dan daerah lainnya, orang menyebutkan Silat. Sedangkan kata pencak sendiri dapat mempunyai arti khusus, begitu juga dengan kata silat.
Suwirman (1999: 11) mengatakan bahwa Pencak silat mempunyai pengertian gerak dasar beladiri yang terikat pada peraturan dan digunakan dalam belajar, latihan, dan pertunjukkan. Silat mempunyai pengertian sebagai gerak bela diri yang sempurna, yang bersumber pada kerohanian yang suci murni, guna menyelamatkan diri atau kesejahteraan bersama, menghindarkan diri/manusia dari bala atau bencana (perampok, penyakit, tenung, dan segala sesuatu yang jahat atau merugikan masyarakat).

Sedangkan definisi pencak silat selengkapnya yang pernah disusun oleh PB. IPSI bersama Bakin pada tahun 1975 adalah sebagai berikut :

"Pencak silat adalah hasil budaya manusia Indonesia untuk membela dan mempertahankan eksistensi (kemandirian) dan integritasnya (manunggal) terhadap lingkungan dan alam sekitarnya untuk mencapai keselarasan hidup guna meningkatkan iman dan taqwa kepada Tuhan Yang Maha Esa.”

Dalam pertandingan pencak silat mempunyai beberapa kategori, yaitu kategori tanding, tunggal, ganda, dan regu. Menurut Lubis (2004:7) menyatakan bahwa : "Kategori tanding adalah kategori yang menampilkan dua orang pesilat dari kubu yang berbeda. Keduanya saling berhadapan menggunakan unsur pembelaan dan serangan,yaitu menangkis / mengelak / mengena / menyerang pada sasaran dan menjatuhkan lawan, penggunaan taktik dan teknik bertanding, ketahanan stamina dan semangat juang, menggunakan kaidah dan pola langkah yang memanfaatkan kekayaan teknik jurus, untuk mendapatkan nilai terbanyak".

Dari uraian diatas pencak silat mempunyai peran sebagai sarana dan prasarana untuk membentuk manusia yang seutuhnya, sehat jasmani (kuat, terampil, tangkas, tenang, sabar, bersifat kesatria, percaya pada diri sendiri) dan memiliki akhlak yang mulia. Dan pencak silat sangat memerlukan ketahanan stamina dalam bertanding, sehingga seorang pesilat dapat melakukan teknik-teknik yang dimilikinya dengan baik sehingga bisa mendapatkan nilai yang banyak.

Harsono (1988: 172) berpendapat kelincahan merupakan kemampuan untuk mengubah arah dan posisi tubuh dengan tepat pada waktu sedang bergerak, tanpa kehilangan keseimbangan dan kesadaran akan posisi tubuhnya. Dari batasan di atas menunjukan kesamaan konseptual sehingga dapat diambil 
suatu pengertian. Adapun yang dimaksudkan dengan kelincahan adalah kemampuan bergerak untuk mengubah arah dan posisi dengan cepat dan tepat sehingga memberikan kemungkinan seseorang untuk melakukan gerakan kearah yang berlawanan dan mengatasi situasi yang dihadapi lebih cepat dan lebih efisien.

Menurut Dangsina Moeloek dan Arjadino Tjokro(1984:8), kelincahan adalah kemampuan mengubah secara cepat arah tubuh atau bagian tubuh tanpa gangguan pada keseimbangan. Mengubah arah gerakan tubuh secara berulangulang seperti halnya lari Dodging Run memerlukan kontraksi secara bergantian pada kelompok otot tertentu.. Massa tubuh seorang atlet relatif konstan tetapi kecepatan dapat ditingkatkan melalui pada rogram latihan dan pengembangan otot. Diantara atlet yang beratnya sama (massa sama), atlet yang memiliki otot yang lebih kuat dalam kelincahan akan lebih unggul (Baley, James A. 1986 : 199).

Tendangan sebagai bagian dari teknik pencak silat memerlukan kelincahan. Hal ini dapat dilihat pada kenyataan yang menunjukkan bahwa pada saat melakukan tendangan, pesilat biasanya melakukan tendangan dengan mengangkat satu kaki. Keadaan tersebut jika ditinjau dari derajat kestabilan akan mengakibatkan terganggunya kelincahan.Ini dikarenakan bidang dasarnya sebagai tumpuan sangat kecil dan titik badan serta berat badan berubah.Untuk mempertahankan dan menjaga kelincahan tubuh tersebut, sebaiknya seorang pesilat cepat menarik tendangan atau dengan membengkokkan lutut tungkai yang dipakai menumpu saat melakukan tendangan. Dengan melakukan hal tersebut titik berat badan akan menjadi lebih rendah, sehingga tubuh menjadi kuat.

Daya ledak otot tungkai adalah kemampuan otot untuk mengatasi beban dan tahanan dengan kecepatan kontraksi yang sangat tinggi. Daya ledak otot tungkai merupakan gabungan dari dua kemampuan yaitu kekuatan (strength) dan kecepatan (speed), dimana kekuatan dan kecepatan dikerahkan maksimum dalam waktu yang sangat cepat dan singkat. Dalam olahraga pencak silat sangat diperlukan daya ledak otot tungkai, terutama saat melakukan tendangan. Otot tungkai atau dikenal dengan Musculus Quadriceps adalah gabungan dari kekuatan otot tungkai paha atas dan otot tungkai bawah saat berkontraksi hingga relaksasi yang diperlukan dalam melakukan tendangan sabit secepat mungkin.

\section{a) Otot tungkai atas}

Otot tungkai atas terdiri dari tiga bagian yaitu: Hamstrings, Quadriceps femoris, Adductors, yang terdiri dari tricep femoris dan bicep femoris. Otot tersebut terletak pada batas pangkal paha sampai sendi lutut. Seperti pada gambar dibawah ini dilihat dari pandangan anterior dan posterior.

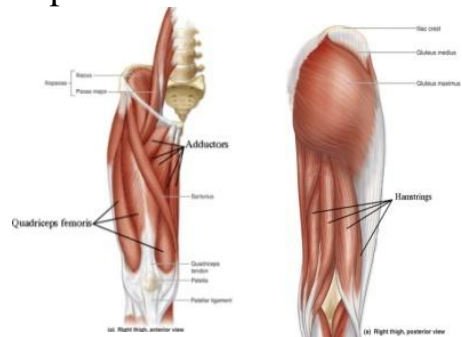

Gambar 1. Otot-otot superfisial dari paha kanan, pandangan anterior dan posterior. (Pearce, 2008 : 113)

b) Otot tungkai bawah

Otot tungkai bawah terdiri dari tiga bagian yaitu: flexores, extensors dan perinci otot. Ketiga otot tersebut pada batas bagian lutut bawah, seperti pada gambar di bawah ini:
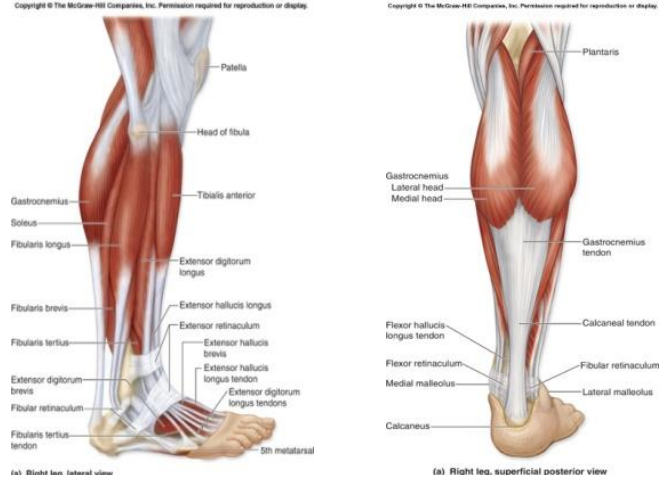

Gambar 2.Otot-otot kaki kanan, pandangan lateral dan superfisial posterior. (Pearce, 2008 : 114)

Tendangan dalam olahraga pencak silat sangat mengutamakan daya ledak otot tungkai pada seorang pesilat, apalagi saat melakukan tendangan yang kuat secara explosive. Jika daya ledak otot tungkai seorang pesilat rendah saat melakukan tendangan, maka tendangan yang dilakukan akan mudah diantisipasi dan sangat menguntungkan bagi lawan, karena lawan dapat melakukan teknik bantingan sehingga mendapatkan point atau nilai.

c) Serabut otot

Serabut otot yang menggerakkan anggota tubuh terdiri dari dua golongan yaitu serabut otot lambat (slow twitch) dan serabut otot cepat (fast twitch). Serabut otot cepat lebih sedikit mengandung kadar kapiler dibanding dengan serabut otot lambat, sehingga serabut otot ini 
juga disebut serabut otot putih. Serabut otot lambat warnanya lebih merah. Hal ini disebabkan banyak mengandung kadar kapiler karena serabut otot lambat disebut juga serabut otot merah.

Otot cepat lebih kuat bekerja secara anaerobic yang menyebabkan reaksi dan kontraksinya juga menjadi cepat. Hal ini disebabkan karena jumlah reticulum sarcoplasmanya lebih banyak, maka proses pelepasannya berlangsung dengan cepat. Dengan kapiler yang sedikit maka, pemasokan darah ke tempat-tempat yang membutuhkan menjadi terbatas. Kontraksinya berlangsung lebih cepat dan cepat pula menjadi lelah, karena memiliki diameter serabut otot yang lebih besar dibandingkan dengan serabut otot lambat, maka jenis serabut otot ini dapat menampilkan kontraksi cepat dan kuat. Dengan demikian serabut otot ini lebih baik untuk kegiatankegiatan dalam waktu yang singkat. Dengan mengetahui jenis dan sifat serabut di atas, maka dapat diketahui bahwa untuk daya ledak jenis otot yang digunakan adalah serabut otot cepat, karena jenis serabut otot ini dapat menampilkan kontraksi otot yang cepat dan kuat, dimana kecepatan dan kekuatan sangat dibutuhkan dalam daya ledak otot tungkai ini.

Kecepatan adalah kemampuan untuk bergerak dengan sangat baik, tepat dan cepat (Jarver dalam Arsil, 1999:83). Martin dalam syafruddin (1996) mengatakan kecepatan merupakan bagian dari kondisi fisik yang sangat penting peranannya untuk meningkatkan prestasi olahraga pada umumnya. Dalam ilmu fisika didefenisikan sebagai jarak persatuan waktu.Menurut Arsil (1999:83), kecepatan merupakan kemampuan tubuh mengarahkan semua sistemnya dalam melawan beban, jarak dan waktu yang mengahasilkan kerja mekanik.

Jadi dari pendapat ahli di atas dapat diambil kesimpulan bahwa kecepatan adalah kemampuan tubuh dalam melawan beban dengan menempuh jarak dalam tempo atau waktu yang sesingkat - singkatnya dengan gerakan yang baik. Kecepatan sangat bergantung dari kekuatan (langsung) karena tanpa kekuatan, kecepatan tidak akan dapat dikembangkan apabila seorang pesilat ingin mengembangkan kecepatan maksimalnya maka, dia juga harus mengembangkan kekuatan, keterkaitan antara kecepatan dan kekuatan pada dasarnya bertolak belakang.

Tendangan sabit merupakan salah satu dari bentuk serangan dalam pencak silat. Menurut
Hamdani dalam Sofia (2008 : 11), pengertian serangan adalah usaha pembelaan diri dengan menggunakan lengan (tangan) atau tungkai (kaki), untuk mengenai sasaran tertentu pada tubuh lawan. Adapun serangan dapat dibagi jenisnya berdasarkan alat yang digunakan. Untuk melakukan serangan lengan atau tangan lazim disebut dengan pukulan, dan serangan tungkai kaki atau kaki yang lazim disebut tendangan.Pada serangan tungkai berlaku pula bentuk lintasan sebagaimana serangan lengan. Dalam olahraga pencak silat terdapat bermacam - macam serangan tungkai. Pada dasarnya berpangkal pada gerak dasar kaki itu sendiri, serangan ini terdiri atas : serangan kaki, serangan lutut, sapuan, dan guntingan.

Dalam penelitian ini akan dijelaskan tentang serangan kaki. Secara umum serangan kaki atau tendangan, sedangkan pada waktu melakukan teknik tendangan posisi dan lintasan gerakan kaki dapat melalui :

1. Depan

2. Melingkar/sabit

3. Belakang

4. Samping

Dalam penelitian ini akan mengambil salah satu teknik tendangan yaitu tendangan melingkar/sabit. Tendangan melingkar atau sabit merupakan salah satu teknik serangan dalam pertandingan pencak silat yang menggunakan kaki, dan dilaksanakan dengan kuat dan cepat, salah satu kaki menjadi tumpuan.

Tendangan dapat dikatakan bagus yaitu sesuai dengan teknik yang ada dalam tendangan yakni mempunyai tenaga, arah sesuai dengan sasaran yang hendak dituju (badan lawan). Dalam system penilaian suatu pertandingan baik pertandingan seni ataupun laga, gerakan tendangan yang mendapat nilai bagus adalah tendangan yang sesuai dengan teknik dan untuk mendapatkan tendangan yang bagus haruslah ditunjang dengan latihan, baik itu latihan fisik maupun dengan latihan teknik dan seorang pelatih tentu sudah mengetahui dengan baik bagaimana program latihan yang hendak diberikan kepada atlet agar sasaran yang diinginkan dapat tercapai dengan baik nantinya. Sehingga melahirkan suatu prestasi yang membanggakan bagi atlet, pelatih, perguruan, daerah bahkan bangsa.

\section{Metode Penelitian}

Adapun jenis penelitian ini adalah korelasional.Tempat dilaksanakan penelitian ini adalah di Perguruan Pencak Silat Silahturahmi 
Kalumbuk Kecamatan Kuranji Kota Padang. Populasi dalam penelitian adalah seluruh atlet Pencak Silat Silahturahmi Kalumbuk Kecamatan Kuranji Kota Padang yang berjumlah 30 orang. Sampel diambil atau dilakukan dengan purposive random sampling. Maka sampel dalam penelitian ini atlit laki-laki sebanyak 17 orang. Instrumen dalam penelitian yakni Dodging Run untuk tes kelincahan, Vertical Jump utnuk tes daya ledak otot tungkai dan tes Kecepatan Tendangan Sabit dengan melakukan sebanyak lima tendangan kaki kanan dan lima tendangan untuk kaki kiri secepatcepatnya secara bergantian. Pelaksanaan dilakukan tiga kali dan diambil waktu yang terbaik dengan ketinggian sandsack $75 \mathrm{~cm}$ (putri) dan $100 \mathrm{~cm}$ (putra). Data dianalisis dengan terlebih dahulu dilakukan uji persyaratan analisis, meliputi uji normalitas data kemudian data dirubah kedalam bentuk T-Score yang kemudian dilakukan analisis korelasi ganda.

\section{Hasil Penelitian dan Diskusi}

\section{Kelincahan Atlet Pencak Silat Silahturahmi Kalumbuk Kec.Kuranji \\ Padang $\left(\mathbf{X}_{1}\right)$}

Berdasarkan hasil pengukuran dari 30 orang atlet pencak silat yang dijadikan sampel dengan menggunakan alat ukur stopwach dari tes dan pengukuran Dodging Run diperoleh skor maxsimal $=13,31$, dan skor minimum $=19,84$, kemudian menghasilkan mean (rata-rata) $=15,79$, median $=15,44$, modus $=14,63$ dan standar deviasi $=1,46$. Agar lebih jelasnya dapat dilihat tabel distribusi frekuensi di bawah ini:

Tabel 1.

Distribusi Frekuensi Kelincahan Atlet

Pencak Silat Silahturahmi Kalumbuk Kec.Kuranji Padang $\left(\mathbf{X}_{1}\right)$

\begin{tabular}{|c|c|c|c|c|}
\hline \multirow{2}{*}{ No } & \multirow{2}{*}{ Kategori } & \multicolumn{2}{|c|}{ Frekuensi } & Kelas \\
\cline { 3 - 4 } & Fa & Fr & Interval \\
\hline 1 & $\begin{array}{c}\text { Baik } \\
\text { Sekali }\end{array}$ & 1 & 3,33 & $<13,60$ \\
\hline 2 & Baik & 10 & 33,33 & $\begin{array}{c}13,60- \\
15,05\end{array}$ \\
\hline 3 & Cukup & 6 & 20,00 & $\begin{array}{c}15,06- \\
16,51\end{array}$ \\
\hline 4 & Kurang & 10 & 33,33 & $\begin{array}{c}16,52- \\
17,98\end{array}$ \\
\hline 5 & $\begin{array}{c}\text { Kurang } \\
\text { Sekali }\end{array}$ & 3 & 10,00 & $>17,98$ \\
\hline \multicolumn{2}{|c|}{ Total } & 30 & 100,00 & \\
\hline
\end{tabular}

Dari tabel di atas mengenai kelincahan atlet Pencak Silat Silahturahmi Kalumbuk Kec.Kuranji Padang , terlihat bahwa dari 30 orang atlet , 1 orang $(3,33 \%)$ memiliki kelincahan pada rentangan waktu $<13,60$ atau dalam kategori Baik, 10 orang $(33,33 \%)$ memiliki kelincahan pada rentangan waktu 13,60 - 15,05 atau dalam kategori Baik. 6 orang $(20,00 \%)$ memiliki kelincahan pada rentangan waktu 15,06 - 16,51 atau dalam kategori Cukup. 10 orang $(33,33 \%)$ memiliki kelincahan pada rentangan waktu 16,52 - 17,98 atau dalam kategori Kurang dan 3 orang $(10,00 \%)$ memiliki kelincahan pada rentangan waktu $>17,98$ atau dalam kategori Kurang Sekali. Agar lebih jelasnya dapat dilihat gambar histogram di bawah ini :

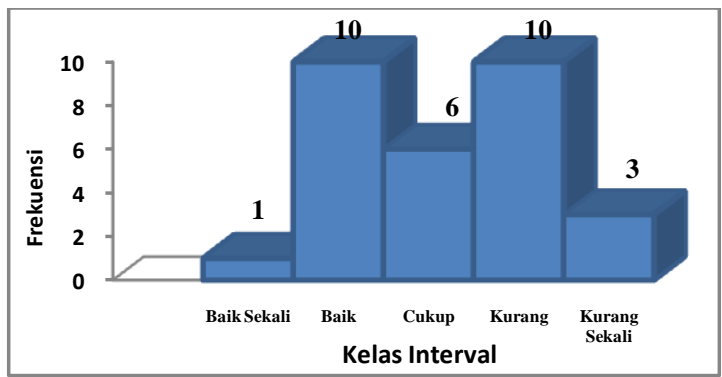

Gambar 3. Grafik Batang Kelincahan Atlet Pencak Silat Silahturahmi Kalumbuk Kec.Kuranji Padang

2. Daya Ledak Otot Tungkai Atlet Pencak Silat Silahturahmi Kalumbuk Kec.Kuranji Padang $\left(\mathbf{X}_{2}\right)$

Berdasarkan hasil pengukuran dari 30 orang atlet pencak silat yang dijadikan sampel dengan menggunakan alat ukur papan skala dari tes dan pengukuran Vertical Jump diperoleh skor maxsimal $=1217,64$, skor minimum $=$ 472,41. kemudian menghasilkan mean (ratarata) $=737,52$, median $=675,60$, modus $=650,80$ dan standar deviasi $=182,40$. Agar lebih jelasnya dapat dilihat tabel distribusi frekuensi di bawah ini:

\section{Tabel 2.}

Distribusi Frekuensi Daya Ledak Otot

Tungkai Atlet Pencak Silat Silahturahmi Kalumbuk Kec.Kuranji Padang $\left(\mathbf{X}_{2}\right)$

\begin{tabular}{|c|c|c|c|c|}
\hline \multirow{2}{*}{ No } & \multirow{2}{*}{ Kategori } & \multicolumn{2}{|c|}{ Frekuensi } & \multirow{2}{*}{$\begin{array}{c}\text { Kelas } \\
\text { Interval }\end{array}$} \\
\hline & & $\mathrm{Fa}$ & $\mathrm{Fr}$ & \\
\hline 1 & $\begin{array}{c}\text { Baik } \\
\text { Sekali }\end{array}$ & 0 & 0,00 & $>1011,12$ \\
\hline 2 & Baik & 11 & 36,67 & $\begin{array}{l}828,72- \\
1011,12\end{array}$ \\
\hline 3 & Cukup & 10 & 33,33 & $\begin{array}{c}646,32- \\
828,12\end{array}$ \\
\hline 4 & Kurang & 8 & 26,67 & $\begin{array}{c}463,92- \\
646,31\end{array}$ \\
\hline 5 & $\begin{array}{l}\text { Kurang } \\
\text { Sekali }\end{array}$ & 1 & 3,33 & $<463,92$ \\
\hline
\end{tabular}




\section{\begin{tabular}{|l|l|l|} 
Total & 30 & 100,00 \\
\hline
\end{tabular}}

Dari tabel di atas mengenai kelincahan atlet pencak silat, terlihat bahwa dari 30 orang atlet, Tidak ada $(0,00 \%)$ memiliki daya ledak otot tungkai pada rentangan kelas interval > 1011,12 atau dalam kategori Baik, 11 orang $(36,67 \%)$ memiliki daya ledak otot tungkai pada rentangan kelas interval $828,72-1011,12$ atau dalam kategori Baik. 10 orang $(33,33 \%)$ memiliki daya ledak otot tungkai pada rentangan kelas interval 646,32 - 828,12 atau dalam kategori Cukup. 8 orang $(26,67 \%)$ memiliki daya ledak otot tungkai pada rentangan kelas interval 463,92 - 646,31 atau dalam kategori Kurang dan 1 orang $(3,33 \%)$ memiliki daya ledak otot tungkai pada rentangan kelas interval < 463,92 atau dalam kategori Kurang Sekali. Agar lebih jelasnya dapat dilihat pada gambar histogram di bawah ini:

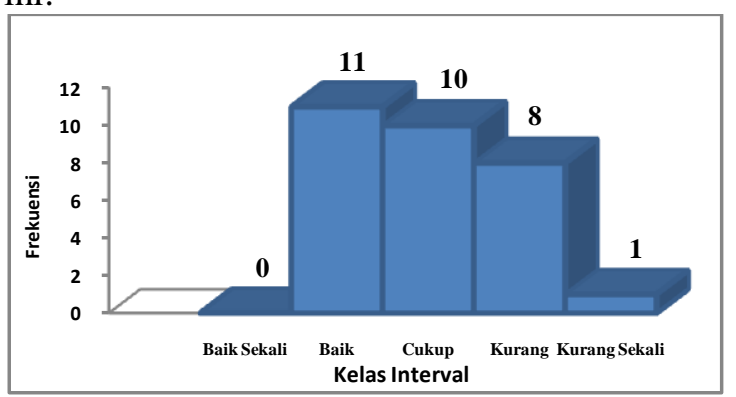

Gambar 4. Grafik Batang Daya Ledak Otot Tungkai Atlet Pencak Silat Silahturahmi Kalumbuk Kec.Kuranji Padang

3. Kecepatan Tendangan Sabit Atlet Pencak Silat Silahturahmi Kalumbuk Kec.Kuranji Padang (Y)

Berdasarkan hasil pengukuran dari 30 orang atlet pencak silat yang dijadikan sampel dengan menggunakan alat ukur stopwach dari tes dan pengukuran kecepatan tendangan sabit dengan bantuan alat samsack diperoleh skor maxsimal $=4,66$, dan skor minimum $=7,94$, kemudian menghasilkan mean (rata-rata) $=5,88$, median $=5,77$, modus $=4,70$ dan standar deviasi $=0,90$. Agar lebih jelasnya dapat dilihat tabel distribusi frekuensi di bawah ini:

Tabel 3.

Distribusi Frekuensi Kecepatan Tendangan Sabit Atlet Pencak Silat Silahturahmi Kalumbuk Kec.Kuranji Padang (Y)

\begin{tabular}{|c|c|c|c|c|}
\hline $\mathrm{N}$ & \multirow{2}{*}{ Kategori } & \multicolumn{2}{|c|}{ Frekuensi } & \multirow{2}{*}{$\begin{array}{c}\text { Kelas } \\
\text { Interval }\end{array}$} \\
\hline o & & $\mathrm{Fa}$ & $\mathrm{Fa}$ & \\
\hline 1 & Baik Sekali & 0 & 0,00 & $<4,53$ \\
\hline
\end{tabular}

\begin{tabular}{|c|c|c|c|c|}
2 & Baik & 10 & 33,33 & $4,53-5,42$ \\
\hline 3 & Cukup & 12 & 40,00 & $5,43-6,32$ \\
\hline 4 & Kurang & 5 & 16,67 & $6,33-7,23$ \\
\hline 5 & $\begin{array}{c}\text { Kurang } \\
\text { Sekali }\end{array}$ & 3 & 10,00 & $>7,23$ \\
\hline & Total & 30 & $\begin{array}{c}100,0 \\
0\end{array}$ & \\
\hline
\end{tabular}

Dari tabel di atas mengenai kelincahan atlet Pencak Silat Silahturahmi Kalumbuk Kec.Kuranji Padang , terlihat bahwa dari 30 orang atlet, tidak ada $(0,00 \%)$ memiliki kecepatan tendangan sabit pada rentangan waktu $<4,53$ atau dalam kategori Baik, 10 orang $(33,33 \%)$ memiliki kecepatan tendangan sabit pada rentangan waktu 4,53 - 547 atsu dalam kategori Baik. 12 orang $(40,($ 30 memiliki kecepatan tendangan sabit pada rumanzan waktu $5,43-6,32$ atau dalam kategori Cukup. 5 orang $(16,67 \%)$ memiliki kecepatan tendangan sabit pada rentangan waktu $6,33-7,23$ atau dalam kategori Kurang dan 3 orang $(10,00 \%)$ memiliki kecepatan tendangan sabit pada rentangan waktu $>$ 7,23 atau dalam kategori Kurang Sekali. Agar lebih jelasnya dapat dilihat gambar histogram di bawah ini :

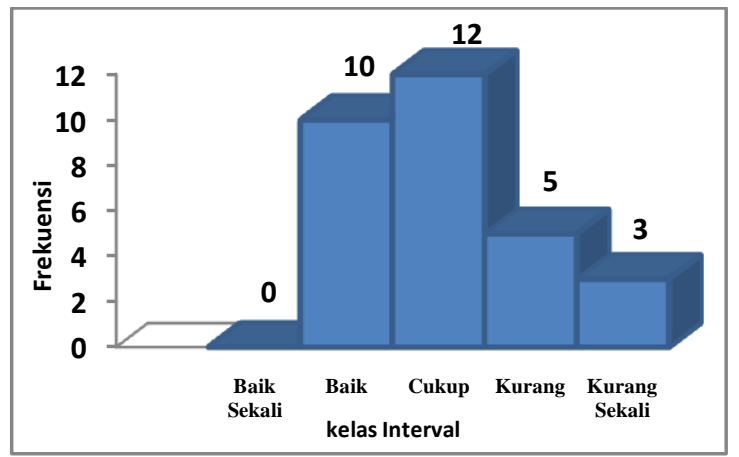

Gambar 9. Grafik Batang Kecepatan Tendangan Sabit Atlet Pencak Silat Silahturahmi Kalumbuk Kec.Kuranji Padang

\section{A. Pengujian Hipotesis}

Sebelum melakukan penoniian Hipotesis tentang kelincahan $\left(\mathrm{X}_{1}\right)$ da 31 । ledak otot tungkai $\left(\mathrm{X}_{2}\right)$ terhadap kecepa......... dangan sabit (Y) terlebih dahulu dilakukan uji persyaratan analisis yaitu uji normalitas sebaran data. Setelah data diuji dengan persyaratan analisis dilakukan uji Hipotesis.

\section{Uji Normalitas}

Uji normalitas sebaran data masing-masing variabel disajikan dalam tabel dibawah ini.

\section{Tabel 4}

Pengukuran Uji Normalitas 


\begin{tabular}{|c|c|c|c|c|c|}
\hline $\begin{array}{l}\mathrm{N} \\
\mathrm{O}\end{array}$ & Variabel & $\mathrm{N}$ & Lo & Ltab & $\begin{array}{l}\text { Distr } \\
\text { ibusi }\end{array}$ \\
\hline 1 & $\begin{array}{c}\text { Kelincahan } \\
\left(\mathrm{X}_{1}\right)\end{array}$ & $\begin{array}{l}3 \\
0\end{array}$ & $\begin{array}{c}0,13 \\
59\end{array}$ & $\begin{array}{c}0,16 \\
1\end{array}$ & $\begin{array}{l}\text { Nor } \\
\text { mal }\end{array}$ \\
\hline 2 & $\begin{array}{c}\text { Daya ledak } \\
\text { otot } \\
\text { tungkai } \\
\left(\mathrm{X}_{2}\right)\end{array}$ & $\begin{array}{l}3 \\
0\end{array}$ & $\begin{array}{c}0,15 \\
12\end{array}$ & $\begin{array}{c}0,16 \\
1\end{array}$ & $\begin{array}{l}\text { Nor } \\
\text { mal }\end{array}$ \\
\hline 3 & $\begin{array}{c}\text { Kecepatan } \\
\text { tendangan } \\
\text { sabit (Y) }\end{array}$ & $\begin{array}{l}3 \\
0\end{array}$ & $\begin{array}{c}0,08 \\
85\end{array}$ & $\begin{array}{c}0,16 \\
1\end{array}$ & $\begin{array}{l}\text { Nor } \\
\text { mal }\end{array}$ \\
\hline
\end{tabular}

Tabel diatas menunjukkan bahwa hasil pengujian untuk kelincahan $\left(\mathrm{X}_{1}\right)$, skor $\mathrm{L}_{\mathrm{o}}=$ 0,1359. dengan $\mathrm{N}=30$ sedangkan $\mathrm{L}_{\text {tab }}$ pada taraf pengujian signifikan $\alpha=0,05$ diperoleh 0,161 yang lebih besar dari $L_{o}$ sehingga dapat disimpulkan bahwa skor yang diperoleh dari kelincahan berdistribusi normal. Selanjutnya hasil tes Daya ledak otot tungkai $\left(\mathrm{X}_{2}\right)$, skor $\mathrm{L}_{\mathrm{O}}=$ 0,1512 dengan $\mathrm{N}=30$ sedangkan $\mathrm{L}_{\text {tab }}$ pada taraf pengujian signifikan $\alpha=0,05$ diperoleh 0,110 yang lebih besar dari $L_{O}$ sehingga dapat disignifikankan bahwa skor yang di peroleh dari daya ledak otot tungkai berdistribusi normal. Agar lebih jelasnya dapat dilihat pada lampiran.

Kemudian diperoleh hasil kecepatan tendangan sabit $(\mathrm{Y})$, skor $\mathrm{L}_{\mathrm{O}}=0,0882$ dengan $\mathrm{n}$ $=30$, sedangkan $\mathrm{L}_{\text {tab }}$ pada taraf pengujian signifikan $\alpha=0,05$ diperoleh 0,161 yang lebih besar dari $\mathrm{L}_{\mathrm{O}}$ sehingga dapat disimpulkan bahwa skor yang diperoleh dari kecepatan tendangan sabit berdistribusi normal. Agar lebih jelas dapat dilihat di lampiran. Berdasarkan uraian diatas ternyata semua variabel $\mathrm{X}_{1}, \mathrm{X}_{2}$, dan $\mathrm{Y}$ ditanya ternyata normal karena masing-masing variabel skor $\mathrm{L}_{\mathrm{O}}$ nya kecil dari pada $\mathrm{L}_{\text {tab }}$ pada pengujian signifikan $\alpha=0,05$. Hal ini berarti bahwa data dari masing-masing variabel penelitian ini tersebut secara normal atau populasi dari mana data sampel diambil berdistribusi normal

\section{Uji Hipotesis}

a. Uji Hipotesis Satu

Berdasarkan hasil analisis kontribusi dari tabel di atas diperoleh kontribusi sebesar $=25 \%$. Hal ini ditandai dengan perolehan $r_{0}=0,497>$ $r_{\text {tab }}=0,361$ pada taraf pengujian signifikan $\alpha=0,05$, artinya terdapat hubungan secara signifikan antara kelincahan dengan kecepatan tendangan sabit Atlet Pencak Silat Silahturahmi Kalumbuk Kec.Kuranji Padang . Oleh sebab itu hipotesis satu dalam penelitian ini diterima.

b. Uji Hipotesis Dua
Berdasarkan hasil analisis kontribusi dari tabel di atas diperoleh kontribusi sebesar $=11 \%$. hal ini ditandai dengan perolehan $r_{0}=0,333<$ $r_{\text {tab }}=0,361$ pada taraf pengujian signifikan $\alpha=0,05$, artinya tidak terdapat hubungan secara signifikan antara daya ledak otot tungkai dengan kecepatan tendangan sabit Atlet Pencak Silat Silahturahmi Kalumbuk Kec.Kuranji Padang. Oleh sebab itu hipotesis dua dalam penelitian ini tidak diterima.

c. Uji Hipotesis Tiga

Berdasarkan hasil analisis kontribusi dari tabel di atas diperoleh kontribusi sebesar= $96,40 \%$. Hal ini ditandai dengan perolehan $\mathrm{r}_{\mathrm{o}}=0,98>\mathrm{L}_{\mathrm{tab}}=0,361$ pada taraf pengujian signifikan $\alpha=0,05$, artinya terdapat hubungan yang signifikan secara bersama-sama antara kelincahan dan Daya ledak otot tungkai secara bersama-sama dengan kecepatan Tendangan Sabit Atlet Pencak Silat Silahturahmi Kalumbuk Kec.Kuranji Padang. Oleh sebab itu hipotesis tiga dalam penelitian ini diterima.

\section{B. Pembahasan \\ 1. Hipotesis Pertama}

Hipotesis pertama yang diajukan dalam penelitian ini adalah sebagai berikut: Kelincahan mempunyai hubungan terhadap kecepatan tendangan sabit Atlet Pencak Silat Silahturahmi Kalumbuk Kec.Kuranji Padang. Untuk mengetahui besarnya kontribusi kelincahan $\left(\mathrm{X}_{1}\right)$ terhadap kecepatan tendangan sabit (Y) digunakan analisis korelasi sederhana. Berdasarkan hasil olahan data, diketahui dengan perolehan $r_{0}=0,497>r_{\text {tab }}=0,361$ pada taraf pengujian signifikan $\alpha=0,05$ ma $\mathrm{ka} \mathrm{H}_{\mathrm{o}}$ ditolak dan $\mathrm{H}_{\mathrm{a}}$ diterima. Hal ini berarti kelincahan $\left(\mathrm{X}_{1}\right)$ berkontribusi sebesar $=25,00 \%$. Artinya terdapat hubungan secara signifikan antara kelincahan dengan kecepatan tendangan sabit Atlet Pencak Silat Silahturahmi Kalt " 34 " Kec.Kuranji Padang.

Kelincahan merupakan seluruh daya dan upaya atlet untuk dapat bergerak dengan cepat, mengubah arah dan posisi, menghindari serangan dari lawan. Dengan kemampuan atlet dalam bergerak mengubah arah dan posisi tergantung pada situasi dan kondisi yang dihadapi dalam waktu yang relatif singkat dan cepat.

\section{Hipotesis Kedua}

Hipotesis kedua yang diajukan dalam penelitian ini adalah sebagai berikut: " Daya ledak otot tungkai tidak memiliki hubungan yang signifikan terhadap kecepatan tendangan sabit Atlet Pencak Silat Silahturahmi Kalumbuk 
Kec.Kuranji Padang. Untuk mengetahui besarnya kontribusi daya ledak otot tungkai $\left(\mathrm{X}_{2}\right)$ terhadap kecepatan tendangan sabit (Y) digunakan analisis korelasi sederhana. Berdasarkan hasil olahan data, diketahui dengan diperoleh $r_{0}=0,333>r_{\text {tab }}=0,361$ pada taraf pengujian signifikan $\alpha=0,05$ ma $\mathrm{ka}_{\mathrm{o}}$ ditolak dan $\mathrm{H}_{\mathrm{a}}$ ditolak. Namun daya ledak otot tungkai $\left(\mathrm{X}_{2}\right)$ berkontribusi sebesar $=11,00 \%$. Artinya tidak terdapat hubungan secara signifikan antara daya ledak otot tungkai dengan kecepatan tendangan sabit Atlet Pencak Silat Silahturahmi Kalumbuk Kec.Kuranji Padang.

Daya ledak merupakan kemampuan untuk menampilkan kekuatan maksimum dan kecepatan maksimum secara eksplisif dalam waktu cepat dan singkat untuk mencapai tujuan yang dikehendaki, sehingga otot yang menampilkan gerakan eksplosif sangat kuat dan cepat dalam berkontraksi. Agar lebih maksimalnya kemampuan daya ledak otot tungkai seorang pesilat, perlu dilakukan beberapa bentuk latihan. Latihan daya ledak otot tungkai dapat dilakukan dengan beban ataupun tanpa beban. Latihan dengan beben yaitu penekankan pada kecepatan mengangkat beban atau mendorong beban latihan.

\section{Hipotesis ketiga}

Hipotesis ketiga yang diajukan dalam penelitian ini adalah sebagai berikut: “ kelincahan dan daya ledak otot tungkai mempunyai kontribusi terhadap terhadap kecepatan tendangan sabit Atlet Pencak Silat Silahturahmi Kalumbuk Kec.Kuranji Padang. Untuk mengetahui besarnya kontribusi Kelincahan $\left(\mathrm{X}_{1}\right)$ dan daya ledak otot tungkai $\left(\mathrm{X}_{2}\right)$ terhadap kecepatan tendangan sabit $(\mathrm{Y})$ digunakan analisis korelasi ganda.

Kecepatan merupakan kemampuan tubuh mengarahkan semua sistemnya dalam melawan beban, jarak dan waktu yang mengahasilkan kerja mekanik. Menurut Robinson dalam Asril (2000) mengatakan "kecepatan bergerak adalah kualitas yang memungkinkan orang bergerak, melaksanakan gerakan - gerakan yang sama atau tidak sama cepat anggota tubuh atau objek yang merupakan kecepatan bergerak".

Berdasarkan hasil olahan data, diperoleh $\mathrm{r}_{\mathrm{o}}=0,98>\mathrm{L}_{\mathrm{tab}}=0,361$ pada taraf pengujian signifikan $\alpha=0,05$ kontribusi sebesar $=46,4 \%$ maka $\mathrm{H}_{\mathrm{o}}$ ditolak dan $\mathrm{H}_{\mathrm{a}}$ diterima. Hal ini berarti kelincahan $\left(\mathrm{X}_{1}\right)$ dan daya ledak otot tungkai $\left(X_{2}\right)$ berkontribusi sebesar $=96,40 \%$. Artinya terdapat hubungan yang signifikan secara bersama-sama antara kelincahan, Daya ledak otot tungkai secara bersama-sama dengan kecepatan tendangan sabit Atlet Pencak Silat Silahturahmi Kalumbuk Kec.Kuranji Padang. Apabila seorang atlet dapat melakukan tendangan sabit dengan baik, dapat membantu pergerakannya, sehingga lawan sukar untuk membaca pergerakan serta mengalami kesulitan dalam serangan. Namun sebaliknya, apabila seorang atlet tidak dapat melakukan tendangan sabit dengan baik, maka pergerakan tendangannya akaan mudah ditebak arahnya sehingga lawan akan mudah melakukan serangan balik.

Hal ini sejalan dengan penjelasan diatas. Di dalam olahraga pencak silat, kondisi fisik merupakan salah satu persyaratan seorang atlet, bahkan dapat dikatakan dasar olahraga prestasi. Untuk itu jelaslah bahwa dalam pembinaan atau latihan dalam olahraga pencak silat, para pembina, pelatih, ataupun para pesilat sangat perlu sekali memperhatikan faktor-faktor fisik yang mempengaruhi dalam olahraga pencak silat, khususnya kelincahan dan daya ledak otot tungkai untuk mendapatkan kecepatan tendangan yang optimal. Selain hal-hal yang telah diuraikan di atas, perlu diperhatikan untuk menjadi atlet yang baik tentu tidak terbatas pada kelincahan dan daya ledak otot tungkai saja. Faktor lain yang perlu diperhatikan adalah: 1).Sikap mental, 2).Disiplin, 3).Penguasaan teknik-teknik dasar dan 4).Penguasaan taktik.

\section{Kesimpulan}

Berdasarkan data yang dikumpulkan dan diolah dengan analisis statistik deskritif pada taraf signifikan 0,05 dengan Exel pengujian hipotesis menghasilkan kesimpulan :

1. Terdapat hubungan antara kelincahan terhadap Kecepatan Tendangan Sabit Atlet Pencak Silat Silahturahmi Kalumbuk Kec.Kuranji Padang dan memberikan kontribusi sebesar $25,00 \%$

2. Tidak Terdapat hubungan antara daya ledak otot tungkai terhadap Kecepatan Tendangan Sabit Atlet Pencak Silat Silahturahmi Kalumbuk Kec.Kuranji Padang dan namun memberikan kontribusi sebesar $11,00 \%$

3. Terdapat hubungan antara kelincahan dan daya ledak otot tungkai secara bersama-sama terhadap Kecepatan Tendangan Sabit Atlet Pencak Silat Silahturahmi Kalumbuk Kec.Kuranji Padang dan memberikan kontribusi sebesar $96,40 \%$

\section{DAFTAR PUSTAKA}


(2007). Buku Panduan Penulisan

Tugas Akhir Universitas Negeri

Padang. Padang. UNP

Arsil. (1999). Pembinaan Kondisi Fisik. Padang : FIK UNP

Baley, James A. (1986). Pedoman Atlet Tehnik Peningkatan Ketangkasan dan Stamina. Semarang : Bahasa Prise

Dangnisa Moeloek dan Arjadino Tjokro. (1984). Kesehatan dan Olahraga. Jakarta : Fakultas Kedokteran Universitas Indonesia

Hariyadi, Slamet. (2002). Tehnik Dasar Pencak Silat Tanding. Jakarta : Dian Rakyat

Harsono. (1988). Coaching dan Aspek-aspek Psikologi dalam Coaching. Jakarta : PT. Dikjen Dikti PPLT

Lubis, Johansyah. (2004). Pencak Silat Panduan Praktis. Jakarta : PT. RajaGrafindo Persada

Fitri, Sari (2008). Pengaruh Keseimbangan dan Daya Ledak Otot Tungkai Terhadap Kemampuan Tendanngan Depan pada Atlet Pencak Silat (Studi pada Atlet PPLP Sumbar Tahun 2007). Skripsi. FIK. UNP

Kementrian Negara Pemuda dan Olahraga. (2006). UU RI No.3 Tahun 2005 tentang Sistem Keolahragaan Nasional. Yogyakarta. Pustaka Yustisia

M. Sajoto. (1995). Pembinaan Kondisi Fisik Olahraga. Jakarta : Depdikbud Dirjen Dikti PPLPTK

Mulyono. (2005). Hubungan Antara Kekuatan Otot Tungkai dan Kelincahan dengan Kecepatan Menggiring bola Pada Siswa Lembaga pendidikan Sepakbola (SPLB). Skripsi. FIK UNNES

Suwirman, (1999). Pencak silat dasar. Dip Proyek UNP.

Suharno HP. (1985). Ilmu Kepelatihan Olahrga. Yogyakarta

Syafrudin. B. (2010). Kontribusi kelincahan dan kelentukan terhadap keterampilan Dribbling pada pemain sepakbola sekolah dasar Negeri 13 Tanjung sani Kabupaten Agam. Skripsi. FIK UNP. 